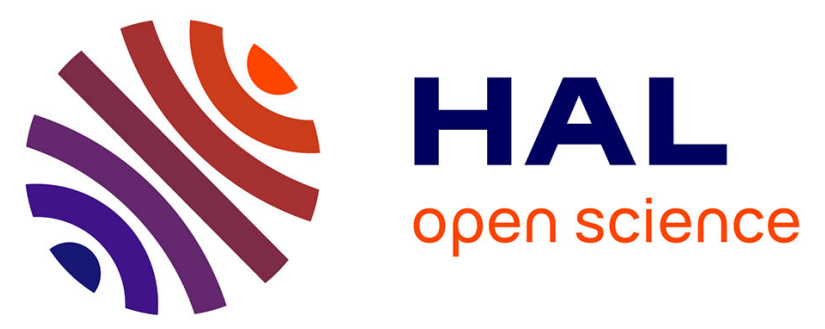

\title{
The Past Occurrence of the Guadeloupe Big-Eyed Bat Chiroderma improvisum Baker and Genoways, 1976 on Marie-Galante (French West Indies) with comments on Bat Remains from Pre-Columbian Sites in the Eastern Caribbean
}

\author{
Arnaud Lenoble
}

\section{To cite this version:}

Arnaud Lenoble. The Past Occurrence of the Guadeloupe Big-Eyed Bat Chiroderma improvisum Baker and Genoways, 1976 on Marie-Galante (French West Indies) with comments on Bat Remains from Pre-Columbian Sites in the Eastern Caribbean. Acta Chiropterologica, 2019, 21 (2), pp.299. 10.3161/15081109ACC2019.21.2.005 . halshs-02500872

\section{HAL Id: halshs-02500872 \\ https://shs.hal.science/halshs-02500872}

Submitted on 7 Dec 2020

HAL is a multi-disciplinary open access archive for the deposit and dissemination of scientific research documents, whether they are published or not. The documents may come from teaching and research institutions in France or abroad, or from public or private research centers.
L'archive ouverte pluridisciplinaire HAL, est destinée au dépôt et à la diffusion de documents scientifiques de niveau recherche, publiés ou non, émanant des établissements d'enseignement et de recherche français ou étrangers, des laboratoires publics ou privés. 
The past occurrence of the Guadeloupe big-eyed bat Chiroderma improvisum Baker and Genoways, 1976 on Marie-Galante (French West Indies) with comments on bat remains from pre-Columbian sites in the Eastern Caribbean

\author{
ARNAUD LENOBLE ${ }^{1,2}$ \\ ${ }^{1}$ UMR CNRS 5199 PACEA, University of Bordeaux, B2 - Allee Geoffroy Saint-Hilaire, CS 50023, \\ 33615 PESSAC, CEDEX, France \\ ${ }^{2}$ Corresponding author: E-mail: arnaud.lenoble@u-bordeaux.fr
}

\title{
Abstract
}

The present work reports the first Quaternary specimen of the Guadeloupe big-eyed bat Chiroderma improvisum represented by a left mandible fragment collected from a pre-Columbian midden on Marie-Galante in the Lesser Antilles. The subfossil material was identified based on the description of the morphology of the mandible and lower molar of modern C. improvisum specimens and a comparison with other previously described Chiroderma species. In addition to being the first documented occurrence of $C$. improvisum on Marie-Galante, it extends the known geographic distribution of this species further south and increases the number of bat species extirpated from the island. A series of associated radiocarbon dates reliably places the last occurrence of this species to between the 11th and 13th centuries, suggesting that some local bat extinctions occurred during the historical period. In addition, a review of bat remains from archaeological contexts in the Eastern Caribbean allows to discuss the possible consumption of bats by indigenous peoples, as well as to stress the potential limitations of the archaeological record for reconstructing past bat communities in this region.

Key words: Chiroderma improvisum, dental morphology, fossil, bat fauna turnover, West Indies, preColumbian subsistance, zooarchaeological epistemology 


\section{INTRODUCTION}

The Caribbean Islands witnessed the largest proportion of mammal extinction in the world since the Late Pleistocene (MacPhee and Flemming, 1999). These extinctions not only completely recast the terrestrial mammal biota (Morgan and Woods, 1986; Davalos and Turvey, 2012) but equally reshaped the flying mammal fauna, although to a lesser extent (Morgan, 2001; Soto-Centeno and Steadman, 2015; Valente et al., 2017). However, explaining the factors underlying these events remains difficult, particularly as they likely result from a combination of several extinction phases that are still difficult to untangle due to the limited number of well-dated extirpation events (Cooke et al., 2017). In addition, regional extinction data are highly variable, with entire areas lacking fossil data (Olson, 1978, 1982). Among these is the Lesser Antilles, whose fossil Chiroptera record is currently both poorly and unevenly documented (Morgan, 2001).

Only four islands of the Lesser Antilles have produced fossil Chiroptera specimens, resulting in an unequal number of identified fossil species, ranging from two and four examples on Anguilla and Barbuda to eight and eleven on Antiqua and Marie-Galante, respectively (Pregill et al., 1994; Orihuela and Tejedor, 2016; Stoetzel et al., 2016). Moreover, specimens of extinct or extirpated species come uniquely from fossil-bearing cave deposits, suggesting a two-fold bias in the available documentation: an over-representation of bat fauna from limestone islands compared with volcanic islands devoid of fossil-bearing sites and a bias towards cave-dwelling species (Pregill et al., 1994; Stoetzel et al., 2016). Thus, several extant bat species are absent from the Lesser Antillean fossil record, such as Eptesicus fuscus, Myotis dominicensis, Sturnira angeli and Chiroderma improvisum.

Among these species, the Guadeloupe big-eyed bat C. improvisum Baker and Genoways, 1976 is a rare bat known uniquely from Guadeloupe, Montserrat, Nevis and St Kitts (Jones and Baker, 1980; Beck et al., 2016) that has only been captured ten times in the last 50 years (Table 1). Here I report a subfossil specimen of $C$. improvisum recovered from a pre-Columbian midden on the island of Marie-Galante in the Lesser Antilles. Comparison with modern specimens allows the mandibular and molar morphology of $C$. improvisum to be described for the first time. My results also expand the geographic distribution of this species in the Lesser Antilles and increase the tally of extirpated bat species from Marie-Galante. This new addition to the well-documented fossil bat record of this island (Stoetzel et al., 2016) indicates greater species diversity during the late Quaternary than was previously documented. Finally, a review of bat remains from pre-Columbian sites in the Eastern Caribbean provides insights concerning the consumption of bats by Amerindian groups and highlights the interest of this type of data for documenting changes in Lesser Antillean bat communities. 


\begin{tabular}{|c|c|c|c|c|c|}
\hline Island & Date & Location & & Voucher specimen & Reference \\
\hline \multirow[t]{5}{*}{ Guadeloupe } & 1974 & la Jaille & pasture adjacent to a gallery forest & TTU 19900 & Baker et al., 1978 \\
\hline & 2000 & Jeannette & pasture and canefield adjacent to the mangrove & - & Kirsch et al. 2000 \\
\hline & 2007 & Sofaia & rainforest & - & Barataud et al. 2015 \\
\hline & 2012 & Piolet & semi-evergreen forest & - & Gomès et al. 2015 \\
\hline & 2014 & Morne Mazeau & rainforest & - & Gomès et al. 2015 \\
\hline \multirow[t]{3}{*}{ Montserrat } & 1978 & Belham River & gallery forest & TTU 31403 & Jones et Baker, 1979 \\
\hline & 1984 & Paradise estate trackway & secondary rainforest & MVZ 166217 & Pierson et al., 1986 \\
\hline & 2005 & - & - & - & Larsen et al., 2007 \\
\hline St Kitts & 2010 & Monkey Hill & private garden, near a fruiting fig tree & - & Beck et al., 2016 \\
\hline Nevis & 2016 & - & - & ROM 126002 & vernet.org \\
\hline
\end{tabular}

TABLE 1. Capture records of $C$. improvisum in the Lesser Antilles

\section{MATERIAL AND METHODS}

The specimen was discovered amongst terrestrial faunal remains from the vertebrate collections stored at the Regional Archaeology Service of Guadeloupe at Le Moule. The subfossil specimen comes from excavated material recovered from the site of Folle Anse, on the western shore of Marie-Galante $\left(15^{\circ} 56^{\prime} 13^{\prime \prime} \mathrm{N}, 61^{\circ} 20^{\prime} 09^{\prime \prime} \mathrm{W}\right)$. This open-air site produced a multi-layered pre-Columbian midden buried in the coastal sand ridge at the edge of the island's western plain. First discovered by M. Barbotin in 1966, the site was excavated over the following years. This work documented an archaeological sequence spanning the Early to Late Ceramic Age (Barbotin, 1970). Current chronological data for the region places the first period between $200 \mathrm{ACE}$ to $600 \mathrm{CE}$, with the second continuing until ca. $1400 \mathrm{CE}$ (Keegan and Hofman, 2017). Part of the faunal assemblage from Barbotin's initial excavations was studied by E. Wing (Wing and Reitz, 1982). New excavations were carried out during three field seasons between 1997 and 2000 (Chenorkian, 1999a, 1999b), with the faunal material from the two first years of excavations studied by S. Grouard (2001) and C. Bochaton (2016). The faunal assemblage recovered during the final excavation season similarly includes the remains of fish, turtles, birds, squamates, and rodents alongside numerous bivalve and gastropod shells. This association was interpreted as a kitchen midden associated with a pre-Columbian village (Wing and Reitz, 1982; Grouard, 2001).

The previously unstudied terrestrial component of the vertebrate assemblage collected during the last year of excavation was recently analysed as part of a project focusing on past biodiversity of Guadeloupe (ECSIT project: ECoSystèmes Insulaires Tropicaux, réponse de la faune terrestre de Guadeloupe à 6,000 ans d'anthropisation du milieu). In the course of this study, a series of ten dates were obtained on bone collagen (one mandible and nine samples from the dentine of incisors) of the extinct rodent Antillomys rayi. 
Measurements on the subfossil specimen were taken using digital calipers. Mandible length was complemented by measurements used by Garbino and Tavarez (2017) in their characterization of the mandibular and dental morphology of the continental species of the genus Chiroderma: buccolingual and mesiodistal width of the $\mathrm{m} 2$, length of $\mathrm{p} 4-\mathrm{m} 2$ tooth row, and angular-coronoid length. The specimen measurements were compared to metric data published by Garbino and Tavarez (2017), as well as measurements taken from photos of the $C$. improvisum holotype preserved in the Texas Tech University Museum (TTU 19900), and of the two voucher specimens of $C$. improvisum, one housed at the same museum (TTU 403 - Jones and Baker, 1979), and the other housed at Museum of Vertebrate Zoology in Berkeley (MVZ 166217 - Pierson et al., 1986). In addition, the subfossil dentary was compared to specimens from French Guyana preserved at Montpellier University (C. trinitatum V1961, C. villosum V-1953), to specimens of Chiroderma from the Smithsonian Institution (USNM) in Washington DC (C. doriae USNM 542616 from Brazil, C. salvini USNM 483743-483748, C. trinitatum USNM 415245-415254, and C. villosum USNM 408679-408684 from Venezuela), and to photos of specimens housed at the Michigan University Museum (UMMZ) and the Texas Tech University Museum (C. trinitatum UMMZ 158061, C. salvini UMMZ 112032, and C. doriae TTU 75275). Terminology for describing the second lower molar cusps and the posterior part of the mandible follows Garbino and Tavarez (2017).

Finally, occurrences of bat remains from Amerindian cave or open-air sites were compiled from the literature. The investigated area corresponds to the Eastern Caribbean region, which includes Puerto Rico, the Virgin Islands, and the Lesser Antilles. The occurrence, number of remains (NR) and minimal number of individuals (MNI) were recorded for terrestrial fauna (bats, birds, squamates, and tortoises).

\section{RESULTS}

The subfossil specimen (Folle Anse archaeological site (FOL) catalogue number: FOL 00-C001) was found amongst material collected during sieving and was accompanied by a label indicating the test pit (Sondage 1), square and sub-square (M2-b2) and date of the finding (8 December 2000). Because the field report for the last year of excavation is unavailable, no additional information linking the spec imen to a particular archaeological level is available. However, the age of the specimen can be estimated by taking into account dates from Antillomys rayi bones recovered during the same excavation. The concordance of the radiocarbon ages supports the excavated material from test-pit Sondage 1 representing the middle phase of the Late Ceramic Age, or between 1050 and 1300 CE (Table 2), thus providing a workable chronology for the midden and its content. 


\begin{tabular}{lllll}
\multicolumn{1}{c}{ Label } & \multicolumn{1}{c}{ Material } & Result & Laboratory reference & Calibrated age (2s) \\
\hline Sd1 M2c1 screening & Antillomys mandible & $805 \pm 25 \mathrm{BP}$ & Lyon-15660(RICH) & $1189-1271 \mathrm{CE}$ \\
Sd1 M2c1 \#593 & Antillomys incisor & $825 \pm 25 \mathrm{BP}$ & Lyon-15661(RICH) \\
Sd1 M2b1 \#101 & Antillomys incisor & $820 \pm 25 \mathrm{BP}$ & Lyon-15455 (RICH) \\
Sd1 M2a2 \#1008 & Antillomys incisor & $835 \pm 25 \mathrm{BP}$ & Lyon-15662(RICH) \\
Sd1 M2b2 \#810 & Antillomys incisor & $825 \pm 25 \mathrm{BP}$ & Lyon-15456(RICH) \\
Sd1 M2a1 \#878 & Antillomys incisor & $890 \pm 25 \mathrm{BP}$ & Lyon-15663(RICH) \\
Sd1 M2c2 \#837 & Antillomys incisor & $795 \pm 25 \mathrm{BP}$ & Lyon-15664(RICH) \\
Sd1 M2a1 \#597 & Antillomys incisor & $840 \pm 25 \mathrm{BP}$ & Lyon-15457 (RICH) \\
Sd1 M2a1 screening & Antillomys incisor & $845 \pm 25 \mathrm{BP}$ & Lyon-15458 (RICH) \\
Sd1 M2c1 screening & Antillomys incisor & $790 \pm 25 \mathrm{BP}$ & Lyon-15665(RICH)
\end{tabular}

TABLE 2. Dating of the Folle Anse vertebrate collection collected during the 2000 field season. Calibrated ages are given as a confidence interval including $95.4 \%$ of the probability distribution

The subfossil specimen is broken at the level of the canine alveolus and preserves the medial and posterior part of a left hemimandible (maximum length $20.1 \mathrm{~mm}$ - Fig. 1). The alveoli of a first singlerooted premolar and a second bi-rooted premolar are present, with a small diastema between the alveoli of the two premolars. The first and second molars, as well as the coronoid, condylar and angular processes are preserved.

Three morphological features of the subfossil, the triangular coronoid process, the coronoid and condylar processes prolonging the ramus in occlusal view, and the angular process prolonging the ramus in lateral view are characteristic of a phyllostomid bat. Within this family, the diastema between the two premolars, the lack of a third molar associated with an elongated second molar with five cusps indicate a bat of the genus Chiroderma (Miller, 1907).

Compared to the morphology of Chiroderma species documented by Garbino and Tavarez (2017), (1) the angular process of the subfossil specimen is wider than it is high in lateral view; (2) the coronoidcondylar crest displays a ' $\mathrm{C}$ '-shape; (3) the post cristid between the hypoconid and the hypo conulid is well developed on the second molar; and (4) the hypoconulid is lingually displaced in occlusal view. These four characters are also present on the three individuals of $\mathcal{C}$. improvisum in the comparison sample, as well as mandibles of $C$. doriae, $C$. trinitatum and $C$. vizottoi (Table 3). Finally, a fifth character is present on both the fossil and modern specimens of $C$. improvisum: the distal position of the metaconid in relation to the protoconid. In the modern specimens of $C$. improvisum from the comparison sample, the metaconid is displaced distally compared to the protoconid (Fig. 2A and 2B), a configuration equally found in C. salvini and C. villosum, while the metaconid is positioned at the same level as the protoconid in C. doriae, C. trinitatum (Fig. 2C) and C. vizottoi. The co-occurrence of these five traits, unique to $C$. improvisum (Table 3 ), may be referred to the subfossil hemimandible to this species. 


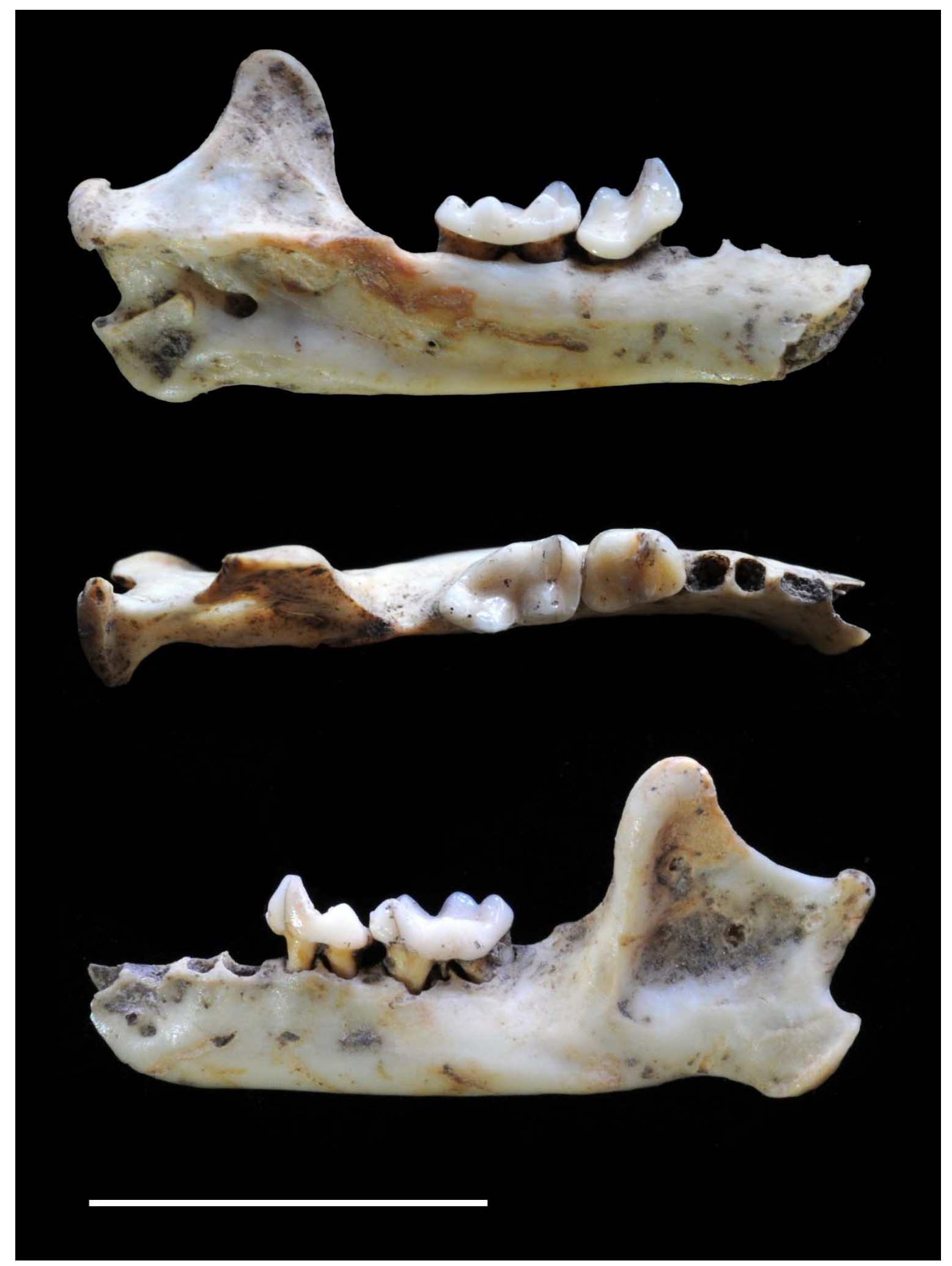

FIG. 1. Lateral, medial and occlusal views of left dentary of $C$. improvisum (FOL 00-C001) from the pre-Columbian site of Folle Anse, Marie-Galante (F.W.I.). Scale bar $=10 \mathrm{~mm}$ 


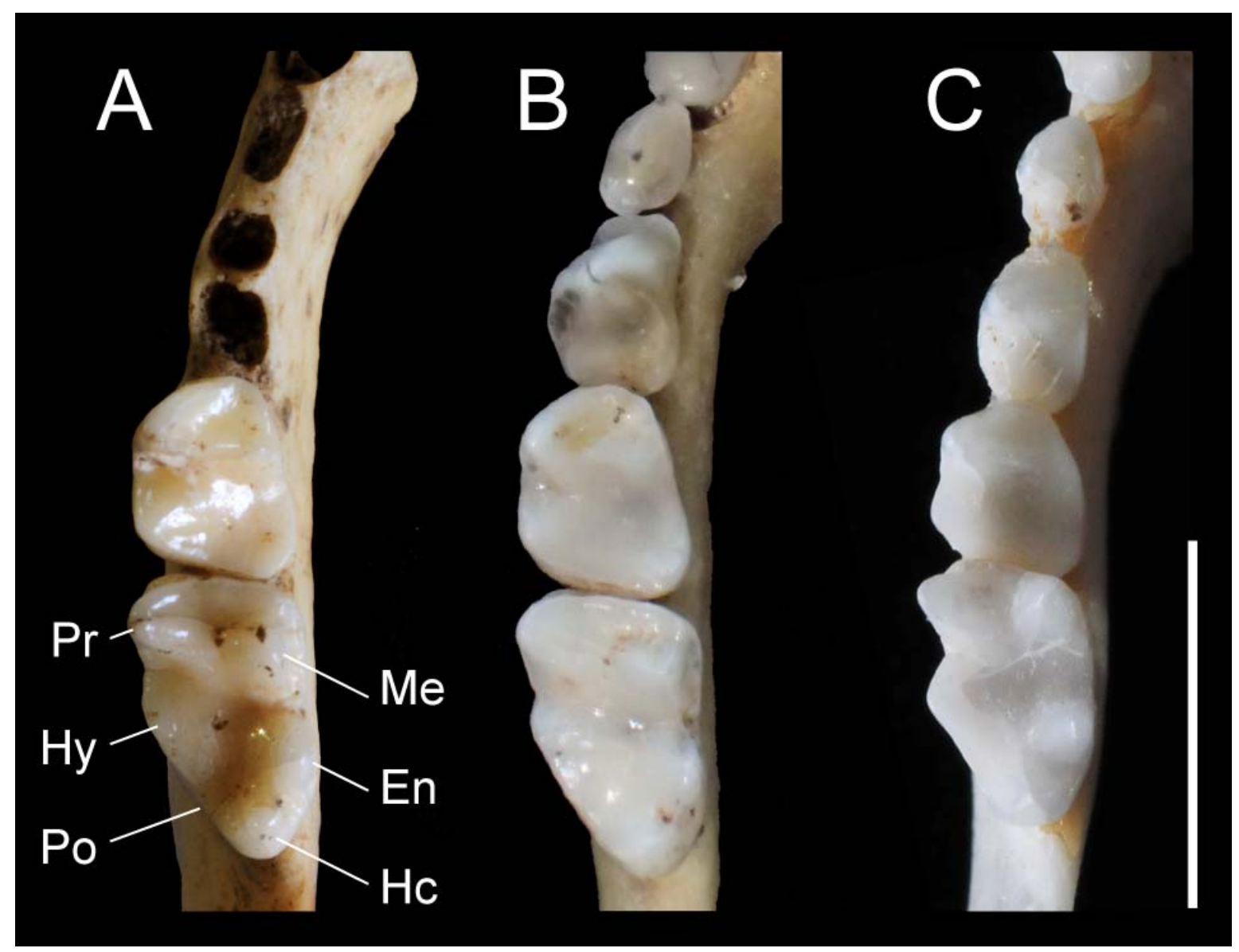

FIG. 2. Occlusal view of $\mathrm{m} 1-\mathrm{m} 2$ in $A-$ the subfossil specimen, B - C. improvisum (TTU 403), and C - C. trinitatum (V-1961). Pr, protoconid; Me, metaconid; Hy, hypoconid; En, entoconid; Hc, hypoconulid; Po, postcristid. Scale bar $=5 \mathrm{~mm}$

\begin{tabular}{ll|cccccc}
\multicolumn{1}{c|}{ Character } & \multicolumn{1}{c}{ State } & C. salvini & C. villosum & C. improvisum & $\begin{array}{c}\text { C. } \\
\text { trinitatium }\end{array}$ & C. vizottoi & C. doriae \\
\hline Ratio L/h PA & $\begin{array}{l}\text { Width and high equal } \\
\text { Wider than high }\end{array}$ & $\mathrm{X}$ & $\mathrm{X}$ & $\mathrm{X}$ & $\mathrm{X}$ & $\mathrm{X}$ & $\mathrm{X}$ \\
\hline $\begin{array}{l}\text { Coronoid-condylar } \\
\text { line }\end{array}$ & $\begin{array}{l}\text { L-shaped } \\
\text { C-shaped }\end{array}$ & $\mathrm{X}$ & $\mathrm{X}$ & $\mathrm{X}$ & $\mathrm{X}$ & $\mathrm{X}$ & $\mathrm{X}$ \\
\hline position hypoconid & $\begin{array}{l}\text { Labially dispaced } \\
\text { Lingually displaced }\end{array}$ & $\mathrm{X}$ & $\mathrm{X}$ & $\mathrm{X}$ & $\mathrm{X}$ & $\mathrm{X}$ & $\mathrm{X}$ \\
\hline $\begin{array}{l}\text { Postcristid } \\
\text { development }\end{array}$ & $\begin{array}{l}\text { Weakly developped } \\
\text { Well developped }\end{array}$ & $\mathrm{X}$ & $\mathrm{X}$ & $\mathrm{X}$ & $\mathrm{X}$ & $\mathrm{X}$ & $\mathrm{X}$ \\
\hline Metaconid & $\begin{array}{l}\text { Anteriorly displaced } \\
\text { Posteriorly displaced }\end{array}$ & $\mathrm{X}$ & $\mathrm{X}$ & $\mathrm{X}$ & $\mathrm{X}$ & $\mathrm{X}$ & $\mathrm{X}$ \\
\hline
\end{tabular}

TABLE 3. Characters of the second lower molar for the different species of the genus Chiroderma 


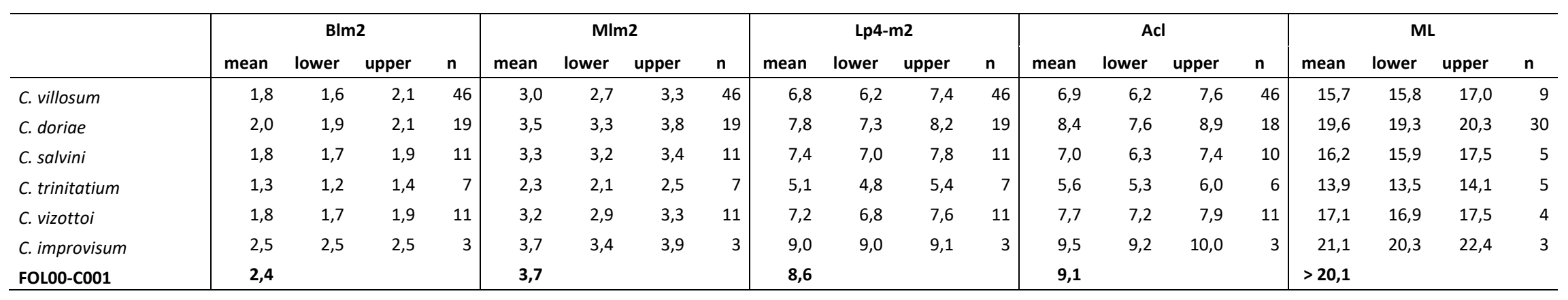

TABLE 4. Mandibular length and $\mathrm{m} 2$ measurements (in $\mathrm{mm}$ ) of the Folle Anse subfossil specimen (FOL 00-CO01) and for the different species of the genus Chiroderma. Measurements are: buccolingual width of $\mathrm{m} 2$ (Blm2), mesiodistal length of $\mathrm{m} 2$ (MIm2), length of p4-m2 toothrow (Lp4-m2), angular-coronoid length ( $\mathrm{Acl})$, and mandibular length (LM). For each measurement and species, the mean, minimum ( $\mathrm{min}$ ) and maximum (max) values, and sample size ( $\mathrm{n}$ ) are given. Mandibular and molar measurements of continental Chiroderma specimens are taken from Taddei and Lim (2010), Rocha et al. (2016), and Garbino and Tavarez (2017); mandibular metrics of C. improvisum include measurements from Baker and Genoways (1976) and Jones and Baker (1979). 
Metric data equally support an attribution to C. improvisum. The Folle Anse dentary is longer than those of modern continental species, and slightly shorter than C. improvisum as a consequence of its fragmentary nature. All other measurements fall within the variability documented for modern specimens of $C$. improvisum (Table 4).

My compilation of faunal assemblages from pre-Columbian deposits in the Eastern Caribbean reveals 19 sites that have yielded bat bones (Table 5). The proportion of bats in the terrestrial vertebrate component expressed in minimal number of individuals ranges from $1 \%$ to around $13 \%$, with a notably high proportion of bat remains from Radio Antilles on Montserrat, which likely reflects the small size of this assemblage. The most frequently identified species is Brachyphylla cavernarum, a phyllostomid cave-dwelling bat documented at nine of the 21 sites. Significant variability in terms of species is also evident with the occurrence of the greater bulldog bat Noctilio leporinus, the big brown bat Eptesicus fuscus, the velvety free-tailed bat Molossus molossus, or the Antillean ghost-faced bat Mormoops blainvillei. The Puerto Rican sites display greater species variability, with five bat species represented in pre-Columbian middens on this island.

No clear difference is evident (Table 5) when the representation of bat remains in pre-Columbian assemblages is considered by period (Early versus Late Ceramic Age). In fact, a Fisher's exact test and $\mathrm{t}$-test do not reject the null hypothesis of an independence between species occurrence and period of occupation (Fisher's exact test: $n=16, P=0.78$ ), and between the ratio of bat remains in the terrestrial vertebrate fauna by period ( $t$-test: t8.569 $=-0,28, P=0.79$ ).

Two factors influencing assemblage composition were also identified. The first is the well-known sampling effect, where the number of bat remains reflects the number of analysed bones (Pearson correlation coefficient with the Hope Estate locality treated as an outlier: $n=11, \rho=0.93, P=0.26 \times 10$ 5). The early Ceramic site of Hope Estate, on St Martin, stands out with an especially low number of bat bones identified in respect to the substantial quantity of bones analysed. This can probably be explained by the fact that the studied material largely derives from the sorting of the coarser fraction of the sieve residue (Grouard, 2004). Sample size equally influences the number of bat species identified, a pattern evinced by the correlation between the number of individuals and number of identified species (Pear son correlation coefficient: $n=18, \rho=0.79, P=9.9 \times 10-5$ ).

The second factor influencing assemblage composition is the relationship between the species identified and the author of the study. This is illustrated by a Fisher's exact test that rejects the null hypothesis of an independence between these variables $(n=24, P=0.0025)$. This cannot be explained by the heterogeneous distribution of species between islands, as the same correlation between 
researchers and identified species is demonstrated when Puerto Rico, whose bat fauna partially differs from that of the Lesser Antilles, is excluded from the analysis (Fisher's exact test: $n=16, P=0.006$ ). Additionally, topography is known to influence the composition of Lesser Antillean bat fauna (Pedersen et al., 2013). The volcanic islands of the internal arc (e.g., Saba, Montserrat, Basse-Terre) shelter a more varied bat fauna bat compared to the limestone islands of the external arc (e.g., Antigua, GrandeTerre, Marie-Galante). However, this effect is not appreciable from the distribution of bats in the archaeological dataset. In fact, island relief and the number of identified species appear to be two perfectly independent variables (Fisher's exact test: $n=15, P=1$ ). Finally, my review of available evidence for the past presence of bats in the region shows the Folle Anse specimen of $C$. improvisum to be the first mention of this species in a pre-Columbian midden.

\section{DISCUSSION}

To date, the osteological descriptions of $C$. improvisum have paid too little attention to the mandible, with metric data limited to mandibular length. Moreover, the description of morphological traits has focused uniquely on cranial elements (Baker and Genoways, 1976; Jones and Baker, 1980). My comparison of the subfossil specimen from Folle Anse with modern specimens of $C$. improvisum and other Chiroderma species revealed morphometric criteria for identifying this species. In addition, my description complements that provided by Garbino and Tavarez (2017) for distinguishing different Chiroderma species. As mandibles are among the anatomical elements most frequently preserved in the archaeological record (e.g., Choate and Birney, 1968; Orihuela and Tejedor, 2016), my results are of particular relevance for identifying bat remains from archaeological or paleontological sites.

The Folle Anse mandible of $C$. improvisum provides the first occurrence of this taxon in the fossil record of the West Indies. It also shows that this tree-dwelling species, which, to date, has only been captured on volcanic islands, was previously present on the flat, carbonate islands of the Lesser Antilles. Moreover, this discovery of this species on Marie-Galante extends its southern distribution as recorded in living specimens. Eight species of bats are currently present on Marie-Galante (Masson et al., 1990b; McCarthy and Henderson, 1992), and seven extirpated (or locally extinct, cf. Morgan, 2001) species are known from the palaeontological record of the island (Stoetzel et al., 2016). The Chiroptera fossil record of Marie-Galante therefore documents the greatest turnover amongst West Indian insular bat fauna since the late Pleistocene (Cooke et al., 2017). The discovery of the Guadeloupe big-eyed bat in the archaeological record of the island increases the number of extirpated species to eight, making Marie-Galante a unique context for exploring the composition of past Caribbean bat communities. In addition, all the extinct species previously identified on the island are cave-dwelling bats (i.e., Phyllonycteris major, mormoopid bats). This pattern reflects both the preference of Caribbean bats for 
cave roosts (Rodríguez-Durán, 2010), as well as the prevalence of drier climatic conditions during the Pleistocene (Stoetzel et al., 2016). With that said, the preservation of palaeontological material in caves also underlies the over-representation of cavedwelling bat species in the Lesser Antillean fossil record (Pregill et al., 1994). The identification of the Guadeloupe big-eyed bat in a pre-Columbian midden shows that extinct species in Marie-Galante to equally include tree-roosting species. This finding illustrates the importance of integrating the archaeological record in order to overcome or offset potential biases of the paleontological record and produce a more accurate assessment of Lesser Antillean past bat communities.

Radiocarbon dates obtained on rodent bones associated with the bat mandible from Folle Anse confidently place the subfossil specimen to the beginning of the second millennium of the present era, indicating that $C$. improvisum disappeared from Marie-Galante sometime between the 13 th and the 20th century. This result makes $C$. improvisum the extirpated bat species of Marie-Galante with the most recent last appearance date, indicating a possibly historic extirpation. While Stoetzel et al. (2016) showed that five of the seven extirpated species from Marie-Galante were still present on the island during the last 8,000 years, they could not pinpoint exactly when they disappeared. The authors therefore argued that direct or indirect human action rather than climate or environmental change during the Pleistocene-Holocene transition drove the reshaping of bat communities. The identification of the Guadeloupe big-eyed bat at Marie-Galante at the end of the pre-Columbian period is consistent with this interpretation. Moreover, the Folle Anse specimen shows that the restructuring of the bat fauna includes at least one very recent extirpation event, which occurred during the last few centuries. The presence of $C$. improvisum in an archaeological kitchen midden equally raises questions concerning its past consumption by indigenous Carib bean populations. In fact, phyllostomid bats continue to be eaten on several islands in the Lesser Antilles (Nègre, 1967), including Martinique, where bats were occasionally hunted as recently as the late 1990s (F. Catzeflis, personal communication), as well as the islands of Guadeloupe (Masson et al., 1990a), where I personally observed bat hunting still being practiced. This is echoed in Oviedo's (1851) historical account of bats as a food source for native populations at the time of the Spanish conquest. According to this account, large bats (phyllostomids?) were considered a delicacy. This similarity between current and past Creole practices suggests bat consumption to be rooted in ancient, pre-Columbian traditions. However, some authors have questioned the reliability of these historical accounts (Rodríguez-Durán, 2002), while others considered the presence of bats bones in archaeological middens as a purely natural phenomenon (Wing et al., 1968). Moreover, Rodriguez-Duran (2002) further considered that the small number of sites and the small quantity of bat bones recovered from pre-Columbian archaeological assemblages did not agree with the hypothesis of bats being consumed as food. Nevertheless, a small number of remains do not contradict the opportunistic hunting and consumption of bats by feeding generalists 
as documented in the Amazon (Setz and Sazima, 1987; Setz, 1991). In addition, increasing evidence of bat remains in pre-Columbian vertebrate assemblages suggests bats to have been consumed by indigenous populations (Steadman et al., 1984; Wing 2001, Orihuela and Tejedor, 2012). Al though bats are relatively small, they are no smaller than several of the forest birds found in Caribbean prehistoric sites (e.g., mimids). The ritual consumption of bats has also been advanced to explain the higher frequency of bat bones in archaeological layers from burial caves (Oliver and Nar ganes Storde, 2005). In any case, the compilation of Amerindian sites in the Eastern Caribbean that have yielded bat remains shows that the presence of bat bones in Amerindian middens is not an anecdotal phenomenon (Table 5). Although only a detailed taphonomic study of bat remains from archaeological vertebrate assemblages could demonstrate the consumption of bats by pre-Columbian peoples, the identification of a subfossil mandible of $C$. improvisum in a pre-Columbian midden provides further evidence supporting the likelihood that phyllostomid were a food source for native Caribbean populations. It also broadens the range of species that may have been consumed.

The singular occurrence of $C$. improvisum suggests it was rarely captured by Amerindians compared to other taxa that appear more frequently in the archaeological record (e.g., B. cavernarum - Table 5). That said, the regional dataset of bat occurrence in archaeological sites should be considered with some caution, as illustrated by the non-independence between authors and identified species. This correlation suggests that not all bat taxa are consistently identified in archaeological assemblages, and that the variety and specific composition of the bat fauna is, consequently, inadequately assessed. Indeed, identifying chiropteran bones in archaeological assemblages currently faces some challenges. Determining vertebrate remains on the basis of partial or fragmentary skeletal elements of taxa whose osteology is poorly described or undocumented and which are otherwise absent from comparative collections is an important and well known limitation of Caribbean zooarchaeology (Lefebvre and Sharpe 2018). The Guadeloupe bigeyed bat perfectly illustrates the type of difficulties that can arise when dealing with rare taxa; only three museums own specimens (Table 1), and only one of these individuals is documented by its skeleton (ROM 126002). As a result, this species is absent from the reference collections usually used for zooarchaeological identification. It is therefore reasonable to believe that the revision of bat remains from additional archaeological contexts may produce $C$. improvisum specimens or, at the very least, rare bat species. Such a revision seems all the more desirable since the archaeological record is likely to both fill gaps in our understanding of the regional mechanisms of extinction, including the identification of extinct species, and provide a more precise chronology for local extinctions (Orihuela and Tejedor, 2012; Cooke et al., 2017). To this aim, the morphological and metric characterization of the mandible and second molar of $C$. improvisum presented here should facilitate the recognition of this taxon in future studies. 


\begin{tabular}{|c|c|c|c|c|c|c|c|c|c|c|c|}
\hline Island & Site & Context & Period & Species & $\begin{array}{c}\text { NR } \\
\text { Chiroptera }\end{array}$ & $\begin{array}{c}\text { NR land } \\
\text { vertebrates }\end{array}$ & $\%$ NR & $\begin{array}{c}\text { NMI } \\
\text { Chiroptera }\end{array}$ & $\begin{array}{c}\text { NMI land } \\
\text { vertebrates }\end{array}$ & $\% \mathrm{NMI}$ & References \\
\hline Antigua & Mill Reef & midden & $\begin{array}{l}\text { Early Ceramic and } \\
\text { early phase of Late } \\
\text { Ceramic }\end{array}$ & Brachyphylla cavernarum & - & - & - & 10 & 518 & $1,9 \%$ & Wing et al., 1968 \\
\hline Antigua & Mudddy Bay (PH-14) & midden & Late Ceramic & Brachyphylla sp. & - & - & - & 1 & - & - & Murphy, 1995 \\
\hline Désirade & Petite Rivière & midden & Early and Late Ceramic & cf. M. molossus & 17 & 1098 & $1,5 \%$ & 2 & 69 & $2,9 \%$ & Grouard, 2001 \\
\hline Guadeloupe & Pointe du Helleux & midden & Late Ceramic & chiroptera indet. & 14 & 669 & $2,1 \%$ & 3 & 23 & $13,0 \%$ & Grouard, 2001 \\
\hline Guadeloupe & Anse à la Gourde & midden & Early Ceramic & cf. M. molossus & 83 & 6086 & $1,4 \%$ & 4 & 106 & $3,8 \%$ & Grouard, 2001 \\
\hline Guadeloupe & La Ramée & midden & Early and Late Ceramic & $\begin{array}{l}\text { Noctilio leporinus } \\
\text { cf. M. molossus }\end{array}$ & 41 & 1552 & $2,6 \%$ & - & - & - & Grouard et al., 2014 \\
\hline Marie Galante & Folle Anse & midden & Early and Late Ceramic & cf. M. molossus & 3 & 121 & $2,5 \%$ & 1 & 26 & $3,8 \%$ & Grouard, 2001 \\
\hline Marie Galante & Taliseronde & midden & Early Ceramic & Brachyphylla cavernarum & - & - & - & - & - & - & Wing \& Reitz, 1982 \\
\hline Marie Galante & Tourlourou & midden & Early and Late Ceramic & cf. Noctilionidae & 5 & 698 & $0,7 \%$ & 3 & 303 & $1,0 \%$ & Grouard et al., 2016 \\
\hline Marie Galante & Tourlourou & midden & Late Ceramic & Brachyphylla cavernarum & 5 & 698 & $0,7 \%$ & 3 & 303 & $1,0 \%$ & Grouard et al., 2016 \\
\hline Martinique & Anse Trabaud & midden & Late Ceramic & M. molossus & 1 & 97 & $1,0 \%$ & 1 & 40 & $2,5 \%$ & Grouard, 2013 \\
\hline Montserrat & Radio Antilles & midden & Early Ceramic & Brachyphylla cavernarum & 1 & 5 & $20,0 \%$ & 1 & 4 & $25,0 \%$ & $\begin{array}{l}\text { Steadman et al., } \\
1984\end{array}$ \\
\hline Nevis & Indian Castle & midden & Late Ceramic & Brachyphylla sp. & - & - & & 1 & 21 & $4,8 \%$ & Wing, 2001 \\
\hline St Martin & Hope Estate & midden & Early Ceramic & M. molossus & 3 & 10304 & $0,03 \%$ & 3 & 881 & $0,1 \%$ & Grouard, 2004 \\
\hline Puerto Rico & San Miguel Cave & Cave & Late Ceramic & $\begin{array}{l}\text { Mormoops blainvillei }(\mathrm{NMI}=1) \\
\text { cf. Eptesicus wetmori }(\mathrm{NMI}=5) \\
\text { Brachyphylla cavernarum }(\mathrm{NMI}=6)\end{array}$ & 18 & - & - & 12 & 88 & $13,6 \%$ & $\begin{array}{l}\text { Oliver \& Narganes } \\
\text { Storde } 2005\end{array}$ \\
\hline Puerto Rico & Finca de Dona Rosa & midden & Late Ceramic & $\begin{array}{l}\text { Mormoops blainvillei }(\mathrm{NMI}=7) \\
\text { cf. Eptesicus wetmori }(\mathrm{NMI}=1) \\
\text { Artibeus jamaicensis }(\mathrm{NMI}=2)\end{array}$ & 20 & - & - & 10 & 142 & $7,0 \%$ & $\begin{array}{l}\text { Oliver \& Narganes } \\
\text { Storde } 2005\end{array}$ \\
\hline Puerto Rico & - & midden & Late Ceramic/Contact & Artibeus jamaicensis & - & - & - & - & - & - & $\begin{array}{l}\text { de France \& } \\
\text { Newson, } 2005\end{array}$ \\
\hline \multirow[t]{2}{*}{ Puerto Rico } & Maisabel & midden & Early Ceramic & Epeticus fuscus & 1 & 1457 & $0,07 \%$ & 1 & 112 & $0,9 \%$ & de France, 1990 \\
\hline & & midden & Late Ceramic & M. molossus & 1 & 60 & $1,7 \%$ & 1 & 12 & $8,3 \%$ & de France, 1990 \\
\hline Saba & Kelbey's Ridge & midden & Early Ceramic & Brachyphylla sp. & - & - & - & 1 & 30 & $3,3 \%$ & Wing, 2001 \\
\hline Saba & Kelbey's Ridge & midden & Late Ceramic & Brachyphylla sp. & - & - & - & 1 & 63 & $1,6 \%$ & Wing, 2001 \\
\hline St Eustache & Golden Rock & midden & $\begin{array}{l}\text { Latest phase of } \\
\text { Early Ceramic }\end{array}$ & chiroptera indet. & - & - & - & 1 & 103 & $1,0 \%$ & $\begin{array}{l}\text { Van der Klift, 1992; } \\
\text { Wing, } 2001\end{array}$ \\
\hline
\end{tabular}

TABLE 5. Occurrences for Chiroptera remains collected in Eastern Caribbean pre-Columbian sites. The number of remains (NR) and the minimal number of individuals (NMI) of both Chiroptera and land vertebrates (land birds, bats, terrestrial herps, and terrestrial mammals) are indicated when known 


\section{ACKNOWLEDGEMENTS}

This study was conducted as a part of the ECSIT Project, conducted by the CNRS with a financial support from the European PO-FEDER program (grant no. 2016-FED-503), the Guadeloupe Regional Council, the DAC of Guadeloupe (PCR Extinctions), and the CNRS (SEEG ECSIT). The author is grate ful to the institutions and scientists who provided photos of comparative specimens: Heath Gartner (Texas Tech University), Chris J. Conroy (Museum of Vertebrate Zoology at Berkeley), and Guilhermo Siniciato Terra Garbino (Universidade Federal de Minas Gerais). Special thanks go to F. Catzeflies who helped organise the loan of specimens from the bat collection of the University of Montpellier. I am also grateful to F. Santos for help with the statistical treatment of the data, and to C. Bochaton and F. Catzeflies for their constructive comments. Johanset Orihuela and the anonymous reviewer are warmly thanked for their suggestions that helped to improve this paper.

\section{LITERATURE CITED}

BAKER, R. J., and H. H. GENOWAYS. 1976. A new species of Chiroderma from Guadeloupe, West Indies (Chiroptera: Phyllostomidae). Occasional Papers of the Museum of Texas Tech University, 39: 1-9.

BAKER, R. J., H. H. GENOWAYS, and J. C. PATTON. 1978. Bats of Guadeloupe. Occasional Papers of the Museum of Texas Tech University, 50: 1-16.

BARATAUD, M., S. GIOSA, F. LEBLANC, P. FAVRE, and J.-F.

DESMET. 2015. Identification et écologie acoustique des chiroptères de la Guadeloupe et de la Martinique (Antilles

Françaises). Vespère, 5: 297-332.

BARBOTIN, M. 1970. Les sites archéologiques de Marie-Galante, Guadeloupe. Pp. 27-44, in Proceedings of the 3rd International Congress for Caribbean Archaeology. Grenada National Museum, Saint-George, Grenade, 158 pp.

BECK, D. J., A. D. LOFTIS, J. L. DALY, W. K. REEVES, and M. V. ORLOVA. 2016. First Record of Chiroderma Improvisum Baker and Genoways, 1976 (Chiroptera: Phyllostomidae) from Saint Kitts, Lesser Antilles. Checklist, 12(2): 1-4.

BOCHATON, C. 2016. Squamates du Pléistocène supérieur et de l'Holocène de l'archipel guadeloupéen: évolution de la biodiversité et interactions avec l'Homme. Thèse de doctorat, Muséum National d'Histoire Naturelle, Paris, 427 pp.

CHENORKIAN, R. 1999a. Folle-Anse (Grand-Bourg de Marie-Galante). Pp. 19-21, in Bilan scientifique de la région Guadeloupe 1997. Ministère de la Culture et de la Communication, direction régionales des affaires culturelles de Guadeloupe, Basse-Terre, Guadeloupe, 51 pp.

CHENORKIAN, R. 1999b. Folle-Anse (Grand-Bourg de Marie-Galante). Pp. 23-24, in Bilan scientifique de la région Guadeloupe 1998. Ministère de la Culture et de la Communication, Direction Régionales des Affaires Culturelles de Guadeloupe, Basse-Terre, Guadeloupe, 52 pp.

CHOATE, J. R., and E. C. BIRNEY. 1968. Sub-recent Insectivora and Chiroptera from Puerto Rico, with the description of 306 a new bat of the genus Stenoderma. Journal of Mammalogy, 49: 400-412.

COOKE, S. B., L. M. DAVALOS, A. M. MYCHAJLIW, S. T. TURVEY, and N. S. UPHAM. 2017. Anthropogenic extinction dominates Holocene declines of West Indian mammals. Annual Review of Ecology, Evolution, and Systematics, 48: 301-327.

DAVALOS, L. M., and S. T. TURVEY. 2012. West Indian mammals: the old, the new, and the recently extinct. Pp. 157-202, in Bones, clones, and biomes: an extended history of recent Neotropical mammals (B. D. PATTERSON and L. P. ACO STA, eds.). University of Chicago Press, Chicago, 432 pp.

DE FRANCE, S. 1990. Zooarchaeological investigations of an early Ceramic Age frontier community in the Caribbean: the Maisabel site, Puerto Rico. Antropologica, 73-74: 3-180. 
DE FRANCE, S., and L. A. NEWSON. 2005. The status of palethnobiological research on Puerto Rico and adjacent islands. Pp. 122-184, in Ancient Borinquen (P. E. SIEGEL, ed.). University of Alabama Press, Tuscaloosa, 423 pp.

GARBINO, G. S. T., and V. De CUNHA TAVAREZ. 2017. A Quaternary record of the big-eyed bat Chiroderma villosum (Chiroptera: Phyllostomidae) with a revised lower molar terminology. Mammalia, 82: 393-399.

GOMÈS, R., B. IBÉNÉ, B. ANGIN, and N. SERRAND. 2015. Le Chiroderme de Guadeloupe. Karubat Niouz, 2: 1617.

GROUARD, S. 2001. Subsistance, systèmes techniques et gestion territoriale en milieu insulaire antillais précolombien: exploitation des vertébrés et des crustacés aux époques Saladoïdes et Troumassoïdes de Guadeloupe (400 av. JC à 1500 ap. JC). Thèse de doctorat, Université Paris X, Paris, 1073 pp.

GROUARD, S. 2004. Variation des stratégies de subsistance des Précolombiens à Hope Estate, Saint-Martin (Petites Antilles), d'après l'analyse des restes des petits vertébrés. Pp. 451-467, in Petits animaux et sociétés humaines (J.-P. BRUGAL and J. DESSE, eds.). Du complément alimentaire aux ressources utilitaires. Editions APDCA, Antibes, 546 pp.

GROUARD, S. 2013. Chasses, pêches et captures de faunes vertébrées et crustacées des occupations côtières récentes du Sud de la Martinique (Saladoïde récent, Vè siècle Ap. J.-C. - Suazoïde récent, XVe s. ap. J.-C.). Pp. 115-161, in Martinique, terre amérindienne. Une approche pluridisciplinaire (B. BÉRARD, ed.). Sidestone Press, Leiden, $278 \mathrm{pp}$.

GROUARD, S. 2016. Les ensembles de faune vertébrée des occupations cedrosan-saladoïdes et troumassantroumassoïdes. Pp. 287-318, in Capesterre-de-Marie-Galante. Stade José Bade: Les occupations cedrosansaladoïde et troumassantroumassoïde de Tourlourous (N. SERRAND, dir.). Inrap GSO, Bègles, 836 pp.

GROUARD, S., S. BAILON, G. PRESTES CARNEIRO, and C. LUJAN ZORRO. 2014. La faune vertébrée. Pp. 94-114, in La Ramée, Ste Rose, Guadeloupe (F. CASAGRANDE, ed.). Inrap GSO, Bègles, 269 pp.

JONES, J. K., JR, and R. J. BAKER. 1979. Notes on a collection of bats from Montserrat, Lesser Antilles. Occasional Papers of the Museum of Texas Tech University, 60: 1-6.

JONES, J. K., JR, and R. J. BAKER. 1980. Chiroderma improvisum. Mammalian Species, 134: 1-2.

KEEGAN, W., and C. L. HOFMAN. 2017. The Caribbean before Columbus. Oxford University Press, New York, $360 \mathrm{pp}$.

KIRSCH, R., G. BENEUX, and T. STOECKLE. 2000. Complément d'inventaire des Chiroptères de Guadeloupe. Rapport de mission. Société Française de Protection et d’Étude des Mammifères, Paris, 18 pp.

LARSEN, R. J., K. A. BOEGLER, H. H. GENOWAYS, W. P. MASEFIELD, R. A. KIRSCH, and S. C. PEDERSEN. 2007. Mist netting bias, species accumulation curves, and the rediscovery of two bats on Montserrat (Lesser Antilles). Acta Chiropterologica, 9: 423-435.

LEFEBVRE, M. J., and A. E. SHARPE. 2018. Contemporary challenges in zooarchaeological specimen identification. Pp. 35-57, in Zooarchaeology in practice: case studies in methodology and interpretation in archaeofaunal analysis (C. M. GIOVAS and M. J. LEFEBVRE, eds.). Springer, Cham, Switzerland, 331 pp.

MASSON, D., C. MASSON, M. BREUIL, and BREUIL A. 1990a. Les chauve-souris de Guadeloupe. Rapport d'étude. Société Française de Protection et d’Étude des Mammifères, Bourges, 43 pp.

MASSON, D., M. BREUIL, and A. BREUIL. 1990b. Premier inventaire des chauves-souris de l'île de Marie-Galante (Antilles françaises). Mammalia, 54: 656-658.

MACPHEE, R. D. E., and C. FLEMMING. 1999. Requiem Æternam: last 500 years of mammal species extinction. Pp. 333-371, in Extinction in near time: causes, contexts, and consequences (R. D. E. MACPHEE, ed.). Kluwer Academic, New York, 394 pp.

MCCARTHY, T. J., and R. W. HENDERSON. 1992. Confirmation of Ardops nichollsi on Marie-Galante, Lesser Antilles, and comments on other bats. Caribbean Journal of Science, 28: 106.

MILLER, G. S., JR. 1907. The families and genera of bats. Bulletin of the United States National Museum, 57: 1282.

MORGAN, G. S. 2001. Patterns of extinction in West Indian bats. Pp. 369-407, in Biogeography of the West Indies (C. A. WOODS and F. E. SERGILE, eds.). CRC Press, Boca Raton, 609 pp. 
MORGAN, G. S., and C. A. WOODS. 1986. Extinction and the zoogeography of West Indian land mammals. Biological Journal of the Linnean Society, 28: 167-203.

MURPHY, A. R. 1995. Archaeological investigations at Muddy Bay (PH-14), Antigua, West Indies: a post-saladoid settlement. M.A. Thesis, Department of Anthropology, Trent University, Peterborough, Canada, viii + 194 pp.

NÈGRE, A. 1967. Les Antilles à travers leur cuisine. Ozanne et Cie, Caen, 222 pp.

OLIVER, J. R., and Y. M. NARGANES STORDE. 2005. The zooarcheological remains from Juan Miguel Cave and Finca de Doña Rosa, Barrio Caguana, Puerto Rico. Ritual edibles or quotidian meals? Pp. 227-242, in Proceedings of the $20^{\text {th }}$ International Congress for Caribbean Archaeology (G. TAVAREZ and M. A. GARCIA AREVALO, eds.). Museo del Hombre Dominicano y Fundación García Arévalo, Sainto-Dominguo, 861 pp.

OLSON, S. L. 1978. A paleontological perspective of West Indian birds and mammals. Pp. 99-117, in Zoogeography in the Caribbean. The 1975 Leidy Medal Symposium (F. B. GILL, ed.). Academy of Natural Sciences of Philadelphia Special Publication, 13: 1-128.

OLSON, S. L. 1982. Biological archeology in the West Indies. Florida Anthropologist, 35: 162-168.

ORIHUELA, J., and A. TEJEDOR. 2012. Peter's ghost-faced bat Mormoops megalophylla (Chiroptera: Mormoopidae) from a pre-Columbian archeological deposit in Cuba. Acta Chiropterologica, 14: 63-72.

ORIHUELA, J., and A. TEJEDOR. 2016. Report of Peter's ghost faced bat Mormoops megalophylla fossils from the island of Barbuda, Lesser Antilles. Chiroptera Neotropical, 21: 1338-1341.

OVIEDO, G. F. DE. 1851. Historia general y natural de las Indias, islas y tierra-firme del mar océano. Primera parte. Imprenta de la Real Academia de la Historia, Madrid, 644 pp.

PEDERSEN, S. C., H. H. GENOWAYS, G. G. KWIECINSKI, P. A.

LARSEN, and R. J. LARSEN. 2013. Biodiversity, biogeography, and conservation of bats in the Lesser Antilles. Pp. 62-73, in Biodiversité insulaire: la flore, la faune et l'homme dans les Petites Antilles. Direction de l'Environnement, de l'Aménagement et du Logement de Martinique et Université des Antilles et de la Guyane, Fort-de-France,

Mar tinique, $192 \mathrm{pp}$.

PIERSON, E. D., R. M. WARNER, and C. C. WHITE-WARNER. 1986. First record of Monophyllus from Montserrat, West Indies. Mammalia, 50: 268-269.

PREGILL, G. K., D. W. STEADMAN, and D. R. WATTERS. 1994. Late Quaternary vertebrate faunas of the Lesser Antilles: historical components of Carribbean biogeography. Bulletin of the Carnegie Museum of Natural History, 30: 1-51.

ROCHA, P. A., M. V. BRANDAO, G. S. T. GARBINO, I. N. CUNHA, and C. C. AIRES. 2016. First record of Salvin's bigeyed bat Chiroderma salvini Dibson, 1878 for Brazil. Mammalia, 80: 573-578.

RODRÍGUEZ-DURÁN, A. 2002. Los murciélagos en las culturas precolombinas de Puerto Rico. Focus, 1(2): 15-18. RODRÍGUEZ-DURÁN, A. 2010. Bat assemblages in the West Indies: the role of caves. Pp. 265-280, in Island bats: evolution, ecology, and conservation (T. H. FLEMING and P. A. RACEY, eds.). University Press of Chicago, Chicago, $560 \mathrm{pp}$.

SETZ, E. Z. F. 1991. Animals in the Nambiquara diet: methods of collection and processing. Journal of Ethnobiology, 11: 1-22.

SETZ, E. Z. F., and I. SAZIMA. 1987. Bats eaten by Nambiquara Indians in western Brazil. Biotropica, 19: 190.

SOTO-CENTENO, J. A., and D. W. STEADMAN. 2015. Fossils reject climate change as the cause of extinction of Caribbean bats. Science Reports, 5: 1-7.

STEADMAN, D. W., D. R. WATTERS, E. J. REITZ, and G. K. PREGILL. 1984. Vertebrates from archaeological sites on Montserrat, West Indies. Annals of Carnegie Museum, 53: 1-29.

STOETZEL, E., A. ROYER, D. COCHARD, and A. LENOBLE. 2016. Late Quaternary changes in bat palaeobiodiversity and palae obiogeography under climatic and anthropogenic pressure: new insights from Marie-Galante, Lesser Antilles. Quaternary Sciences Reviews, 143: 150-174.

TADDEI, V. A., and B. K. LIM. 2010. A new species of Chiroderma (Chiroptera, Phyllostomidae) from Northeastern 
Brazil. Brazilian Journal of Biology, 70: 381-386.

VALENTE, L., R. S. ETIENNE, and L. M. DAVALOS. 2017. Recent extinctions disturb path to equilibrium diversity in Caribbean bats. Nature Ecology and Evolution, 1: 0026.

VAN DER KLIFT, H. M. 1992. Faunal remains of the Golden Rock site. In The archaeology of St. Eustatius, the Golden Rock Site (A. H. VERSTEEG and K. SCHINKEL, eds.). Publication of the Foundation for Scientific Research in the Caribbean Region, 131: 74-84.

WING, E. S. 2001. Native American use of animals in the Caribbean. Pp. 481-518, in Biogeography of the West Indies: patterns and perspectives, 2nd edition (C. A. WOODS and F. E. SERGILE, eds.). CRC, Baco Raton, 609 pp.

WING, E. S., and E. J. REITZ. 1982. Prehistoric fishing economies of the Caribbean. Journal of New World Archaeology, 5: 13-32.

WING, E. S., C. A. HOFFMAN, and C. E. RAY. 1968. Vertebrate remains from Indian Sites on Antigua, West Indies. Caribbean Journal of Science, 8: 123-139. 